\title{
Observations on parasitism in deep-sea hydrothermal vent and seep limpets
}

\author{
Christina M. Terlizzi, Megan E. Ward*, Cindy L. Van Dover \\ Department of Biology, The College of William \& Mary, Williamsburg, Virginia 23185, USA
}

\begin{abstract}
Parasite burdens of shallow-water molluscs have been well documented, but little is known about parasite burdens of molluscs from deep-sea chemosynthetic environments (e.g. hydrothermal vents and seeps). Chemosynthetic habitats are characterized by high concentrations of reduced sulfur and, in the case of vents, high heavy metal concentrations. These compounds are noxious and even stress-inducing in some environments, but are part of the natural chemical milieu of vents and seeps. To examine parasite types and infection intensities in limpets from vents and seeps we documented parasite burdens in 4 limpet species from 4 hydrothermal vent fields ( 3 on the East Pacific Rise, 1 on the Mid-Atlantic Ridge) and 1 seep site (Florida Escarpment). Approximately $50 \%$ of all limpets examined were infected with 1 or more types of parasites. Limpet parasites were predominantly rickettsia-like inclusions in the digestive and gill epithelia. Limpets collected from the vent field on the Mid-Atlantic Ridge were free of parasites. We detected no histopathological effects that we could attribute to parasites.
\end{abstract}

KEY WORDS: Chemosynthetic ecosystems - Rickettsia - Community ecology · Parasite ecology · Mollusc Resale or republication not permitted without written consent of the publisher

\section{INTRODUCTION}

Parasitic infections are common in aquatic communities, including those involving molluscs (Kim et al. 1998, Carballal et al. 2001, Poulin 2002). The effects of parasitic infection can be devastating to individual hosts and to host populations. Infections can impair growth, reproduction and the ability of the animal to compete for resources (Calvo-Ugarteburu \& McQuaid 1998, Ward et al. 2004, this issue). Parasites can affect host population dynamics by influencing the outcome of predation and intra- and interspecific competition, thereby having an impact on the community structure and function of entire ecosystems. Although often overlooked by marine ecologists, interactions between parasites and hosts are as important as predation, facilitation and competition in structuring communities (Anderson 1978, Anderson \& May 1978).

While parasites and their effects have been well documented for shallow-water communities, there are few studies of microparasites in the deep sea. Information on parasitism in chemosynthetic ecosystems, such as hydrothermal vents and cold seeps, is especially sparse. Hydrothermal vents and cold seeps provide an opportunity to study animals in extreme environments (Powell et al. 1999).

Deep-sea hydrothermal vents are characterized by high concentrations of hydrogen sulfide and heavy metals (reviewed in Van Dover 2000). Found along seafloor spreading centers, hydrothermal vents are home to diverse, chemosynthetically based ecosystems. Molluscs living at hydrothermal vents typically live at temperatures 1 to $20^{\circ} \mathrm{C}$ above the ambient 2 to $3^{\circ} \mathrm{C}$ of the surrounding seawater (Van Dover 2000). Sulfides and heavy metals in vent fluids bathing the animal communities are at levels that are normally toxic to aerobic organisms, but vent molluscs are adapted to these conditions (Cosson \& Vivier 1997, Juniper \& Tunnicliffe 1997, Sibuet \& Olu 1998). Cold seeps are a second type of chemosynthetic environ- 


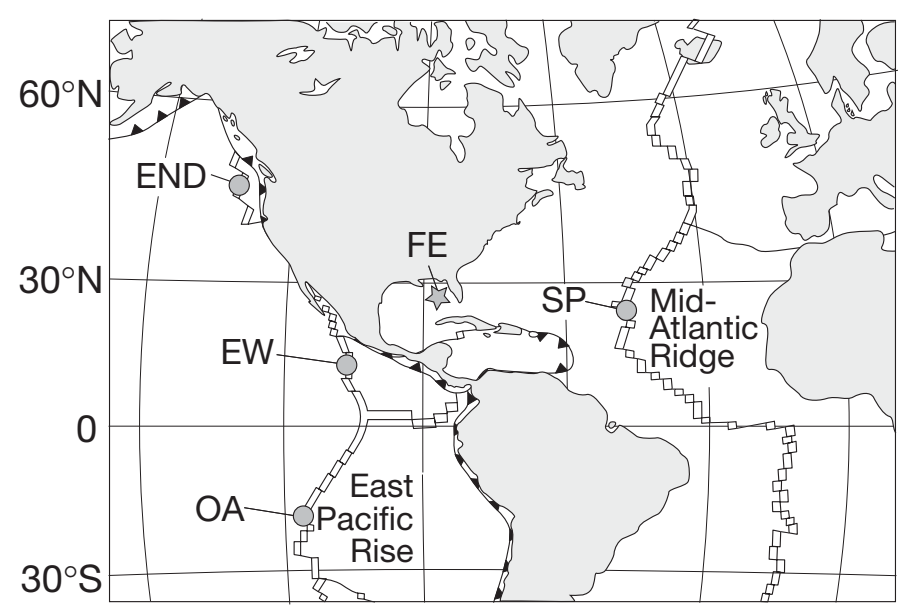

Fig. 1. Limpet collection sites. Grey circles: vents; grey star: seep. OA: Oasis, southern East Pacific Rise $\left(17^{\circ} 25.3^{\prime} \mathrm{S}\right.$, $113^{\circ} 12.3^{\prime} \mathrm{W}, 2582 \mathrm{~m}$; Lepetodrilus elevatus sampled in 1999); EW: East Wall, northern East Pacific Rise $\left(9^{\circ} 50.9^{\prime} \mathrm{N}\right.$, $104^{\circ} 17.5^{\prime} \mathrm{W}, 2499 \mathrm{~m} ;$ L. elevatus sampled in 1999). END: Endeavor, Juan de Fuca Ridge $\left(47^{\circ} 58.00^{\prime} \mathrm{N}, 129^{\circ} 05.50^{\prime} \mathrm{W}\right.$, $2220 \mathrm{~m}$; L. fucensis sampled in 1999). SP: Snake Pit, MidAtlantic Ridge $\left(23^{\circ} 22.1^{\prime} \mathrm{N}, 44^{\circ} 57.0^{\prime} \mathrm{W}, 3490\right.$ m; Pseudorimula midatlantica sampled in 2001). FE: Florida Escarpment $\left(26^{\circ} 01.8^{\prime} \mathrm{N}, 84^{\circ} 54.9^{\prime} \mathrm{W}, 3288 \mathrm{~m}\right.$; Paralepetopsis floridensis sampled in 2000)

ment found in the deep sea (see Sibuet \& Olu 1998). Seeps occur in a variety of geological contexts, including brine seeps (e.g. Florida Escarpment seep; Paull et al. 1984), gas-hydrate seeps (e.g. Blake Ridge; Van Dover et al. 2003), and petroleum seeps (Gulf of Mexico; MacDonald et al. 1990).

Recently, 2 studies have focused on the parasite burdens of bathymodiolin mussels from chemosynthetic systems (Powell et al. 1999, Ward et al. 2004). Both studies documented parasites similar in morphology to those found in coastal molluscs. These types of parasites included rickettsia and chlamydialike cellular inclusions and extracellular gill ciliates (Powell et al. 1999, Ward et al. 2004). Prevalence of some types of parasites, such as rickettsia- and chlamydia-like inclusions, was higher in deep-sea mussels than is typically observed in mussels from intertidal regions. Seep mussels were more heavily parasitized than vent mussels (Ward et al. 2004), possibly due to the greater stability of the seep environment compared to the hydrothermal vent environment (Sibuet \& Olu 1998).

To extend our appreciation of parasite burdens in invertebrates in chemosynthetic environments, we chose to examine parasite burdens in deep-sea hydrothermal vent and seep limpets. Limpets, although small (typically $<1 \mathrm{~cm}$ length), are common and abundant at vents and seeps, and often dominate the macrofaunal biomass. We studied 3 vent species (Lepetodrilus elevatus from 2 sites on the East Pacific Rise [EPR; sampled in 1999], L. fucensis from the Juan de Fuca Ridge [JDR; sampled in 1999], and Pseudorimula midatlantica from the Mid-Atlantic Ridge [MAR; sampled in 2001]) and 1 seep species (Paralepetopsis floridensis from the Florida Escarpment; sampled in 2000) (see Fig. 1 for sample locations). These species are the dominant limpet species at each site and represent 4 biogeographically distinct regions and 2 types of chemosynthetic habitats.

\section{MATERIALS AND METHODS}

All limpets for this study were collected using the research submersible 'Alvin'. Limpets were fixed in $10 \%$ buffered formalin for $24 \mathrm{~h}$ and stored in $70 \%$ ethanol. We selected 25 or 30 limpets of each species at random (except Paralepetopsis floridensis, for which only 8 specimens were selected), and numbered, measured (shell length $\pm 0.1 \mathrm{~mm}$ ) and weighed (tissue wet weight $\pm 0.001 \mathrm{~g}$ ) them

Limpets were embedded in paraffin wax and sectioned (5 to $6 \mu \mathrm{m}$ ) longitudinally. Serial sections were stained with Gill's hematoxylin and eosin (H\&E; Stevens 1990) for parasite identification. Infection prevalences (no. of host individuals infected with any parasite; Margolis et al. 1982) and intensities (no. of individuals of a particular parasite species in each infected host; Margolis et al. 1982) were determined quantitatively for each individual and the sex of each limpet was recorded. Individuals not infected with any parasites were excluded from the calculation of withinsite mean infection intensities. Micrographs of parasites were taken using a Spot camera (Diagnostic Instruments); contrasts were adjusted using Adobe Photoshop (Adobe Systems).

Pearson's correlations and the non-parametric Kruskal-Wallis test where appropriate were undertaken using MINITAB software (Version 13.20, 2000). The multi-dimensional scaling (MDS) technique (PRIMER v5; Clarke \& Gorley 2001) was used to examine differences between individuals based on parasite infection, using Bray-Curtis similarities calculated from the non-transformed infection intensities of parasites from each limpet, excluding individuals that were not infected with any parasites. The relative positions of individual points on MDS plots (unitless, 2D spaces) represent relative similarities of multivariate data for each limpet individual, derived from a parasite-abundance matrix. Analysis of similarity (ANOSIM subroutine of PRIMER v5) was used to determine significant differences between groups distinguished by MDS. ANOSIM provides R statistics: where $\mathrm{R}>0.75$, groups 
are well-separated; where $0.75>\mathrm{R}>0.5$, groups are overlapping but clearly different; where $\mathrm{R}<0.25$, groups are not separable (Clarke \& Gorley 2001). Factors contributing to these differences were determined from similarity percentages (SIMPER subroutine in PRIMER v5).

The limpet Paralepetopsis floridensis lacks gills. This character, plus the reduced sampling effort for $P$. floridensis, forced us to make descriptive rather than quantitative comparisons of parasite burdens between seep and vent limpets.

\section{RESULTS}

\section{Parasite fauna}

We identified 7 types of parasites in histological serial sections of Lepetodrilus elevatus, L. fucensis, Pseudorimula midatlantica, and Paralepetopsis floridensis. These 7 types can be placed into 3 groups: rickettsia-like gut and gill inclusions, gregarine protozoans, and bacterial gut inclusions (Table 1).
We identified 3 rickettsia-like gut inclusions infecting the cytoplasm of the host cell. The first, referred to hereafter as Digestive Rickettsia I (Fig. 2a), was found in the digestive epithelial cells of the stomach of Lepetodrilus elevatus from EPR vents. These basophilic inclusions were generally spherical in shape with an average diameter of $15 \mu \mathrm{m}(\mathrm{n}=10)$. A membrane separated the inclusion from the host cell (Fig. 2b). Obvious tissue pathology was uncommon, although in some cases the inclusion could be seen breaking through the host cell membrane. Another rickettsia-like gut inclusion, referred to as Digestive Rickettsia II, was seen in epithelial cells of the digestive diverticula of $L$. elevatus from EPR vents (Fig. 2c). These inclusions had an average diameter of $12 \mu \mathrm{m}(\mathrm{n}=10)$. Digestive Rickettsia II was characterized by an outer membrane and a grainy, almost filamentous internal structure (Fig. 2d), and were basophilic with H\&E.

The rickettsia-like gill inclusion (referred to as Gill Rickettsia) was observed in the gill epithelial cells of Lepetodrilus elevatus (Fig. 2e) from the Oasis vent (southern EPR) and L. fucensis from the Endeavour

Table 1. Lepetodrilus elevatus, L. fucensis, Pseudorimula midatlantica, and Paralepetopsis floridensis infected by microparasites. Prevalences (as number of host individuals infected and \% of total individuals) and mean infection intensity (SE) of parasite types and copepod infestation data. na: not applicable $(\mathrm{n}<3) ;(\mathrm{n})=$ no. of limpets examined

\begin{tabular}{|c|c|c|c|c|c|}
\hline \multirow[t]{2}{*}{ Parasite type } & \multicolumn{4}{|c|}{ Hydrothermal vent sites } & \multirow{2}{*}{$\begin{array}{c}\text { Seep site } \\
\text { Florida Escarpment } \\
\text { P. floridensis } \\
(\mathrm{n}=8)\end{array}$} \\
\hline & $\begin{array}{l}\text { East Wall } \\
\text { L.elevatus } \\
(\mathrm{n}=30)\end{array}$ & $\begin{array}{l}\text { Oasis } \\
\text { L. elevatus } \\
(\mathrm{n}=25)\end{array}$ & $\begin{array}{l}\text { Juan de Fuca } \\
\text { L. fucensis } \\
(\mathrm{n}=25)\end{array}$ & $\begin{array}{l}\text { Snake Pit } \\
\text { P. midatlantica } \\
(\mathrm{n}=25)\end{array}$ & \\
\hline \multicolumn{6}{|l|}{ Digestive Rickettsia I } \\
\hline No. of limpets infected (\%) & $12(40 \%)$ & $4(16 \%)$ & 0 & 0 & 0 \\
\hline Mean infection intensity $( \pm \mathrm{SE})$ & $3.3(1.3)$ & $11.5(9.2)$ & 0 & 0 & 0 \\
\hline \multicolumn{6}{|l|}{ Digestive Rickettsia II } \\
\hline No. of limpets infected (\%) & $3(10 \%)$ & $9(36 \%)$ & 0 & 0 & 0 \\
\hline Mean infection intensity $( \pm \mathrm{SE})$ & $1.7(0.7)$ & $10.2(6.1)$ & 0 & 0 & 0 \\
\hline \multicolumn{6}{|l|}{ Digestive Rickettsia III } \\
\hline No. of limpets infected (\%) & 0 & 0 & 0 & 0 & $2(25 \%)$ \\
\hline Mean infection intensity $( \pm \mathrm{SE})$ & 0 & 0 & 0 & 0 & 1.5 (na) \\
\hline \multicolumn{6}{|l|}{ Gill Rickettsia } \\
\hline No. of limpets infected (\%) & 0 & $5(20 \%)$ & $5(20 \%)$ & 0 & 0 \\
\hline Mean infection intensity $( \pm \mathrm{SE})$ & 0 & $3.0(1.5)$ & $1.8(0.4)$ & 0 & 0 \\
\hline \multicolumn{6}{|l|}{ Gregarines } \\
\hline No. of limpets infected (\%) & 0 & $2(8 \%)$ & 0 & 0 & 0 \\
\hline Mean infection intensity $( \pm \mathrm{SE})$ & 0 & 4.5 (na) & 0 & 0 & 0 \\
\hline \multicolumn{6}{|l|}{ Bacterial Inclusion I } \\
\hline No. of limpets infected (\%) & $10(33 \%)$ & $4(16 \%)$ & 0 & 0 & $2(25 \%)$ \\
\hline Mean infection intensity $( \pm \mathrm{SE})$ & $6.0(1.6)$ & $6.5(1.6)$ & 0 & 0 & 2 (na) \\
\hline \multicolumn{6}{|l|}{ Bacterial Inclusion II } \\
\hline No. of limpets infected (\%) & 0 & $6(20 \%)$ & $9(36 \%)$ & 0 & 0 \\
\hline Mean infection intensity $( \pm \mathrm{SE})$ & 0 & $56.4(21.6)$ & $34.8(11.9)$ & 0 & 0 \\
\hline \multicolumn{6}{|l|}{ Copepods } \\
\hline No. of limpets infested (\%) & 0 & $1(4 \%)$ & $4(16 \%)$ & $1(4 \%)$ & 0 \\
\hline Infestation intensity $( \pm \mathrm{SE})$ & 0 & 1 (na) & $1(0.0)$ & 1 (na) & 0 \\
\hline
\end{tabular}


vent. These inclusions were similar in size and morphology to Digestive Rickettsia I.

Gregarine protozoans were found only in Lepetodrilus elevatus from the Oasis vent. The gregarines averaged $123 \mu \mathrm{m}(\mathrm{n}=9)$ in length and were aggregated in mantle tissues (Fig. 3a). The oocyst, located within the sporocyst (Fig. 3b) of each gregarine stained bright red or pink with H\&E.
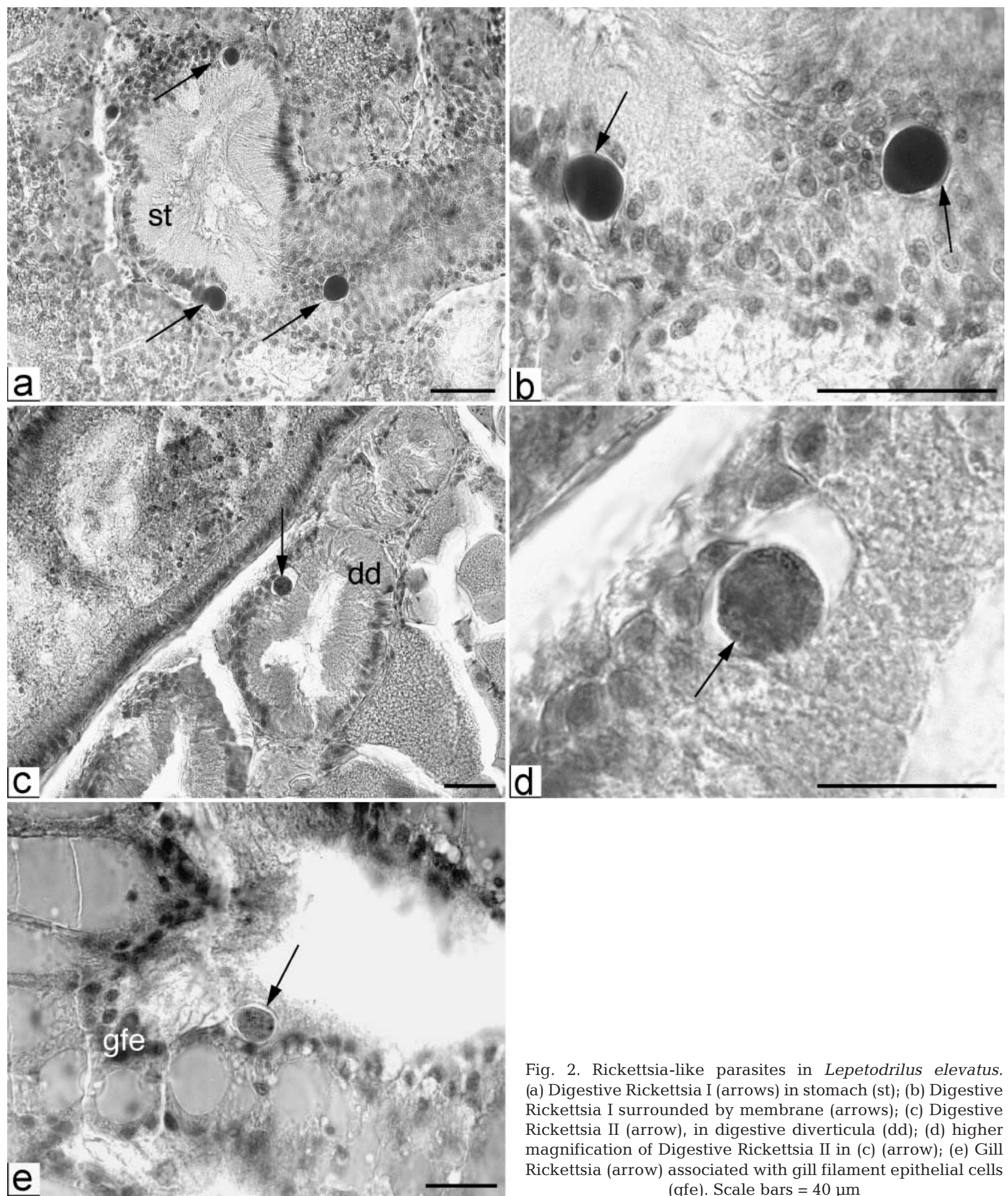

Fig. 2. Rickettsia-like parasites in Lepetodrilus elevatus. (a) Digestive Rickettsia I (arrows) in stomach (st); (b) Digestive Rickettsia I surrounded by membrane (arrows); (c) Digestive Rickettsia II (arrow), in digestive diverticula (dd); (d) higher magnification of Digestive Rickettsia II in (c) (arrow); (e) Gill Rickettsia (arrow) associated with gill filament epithelial cells (gfe). Scale bars $=40 \mu \mathrm{m}$ 

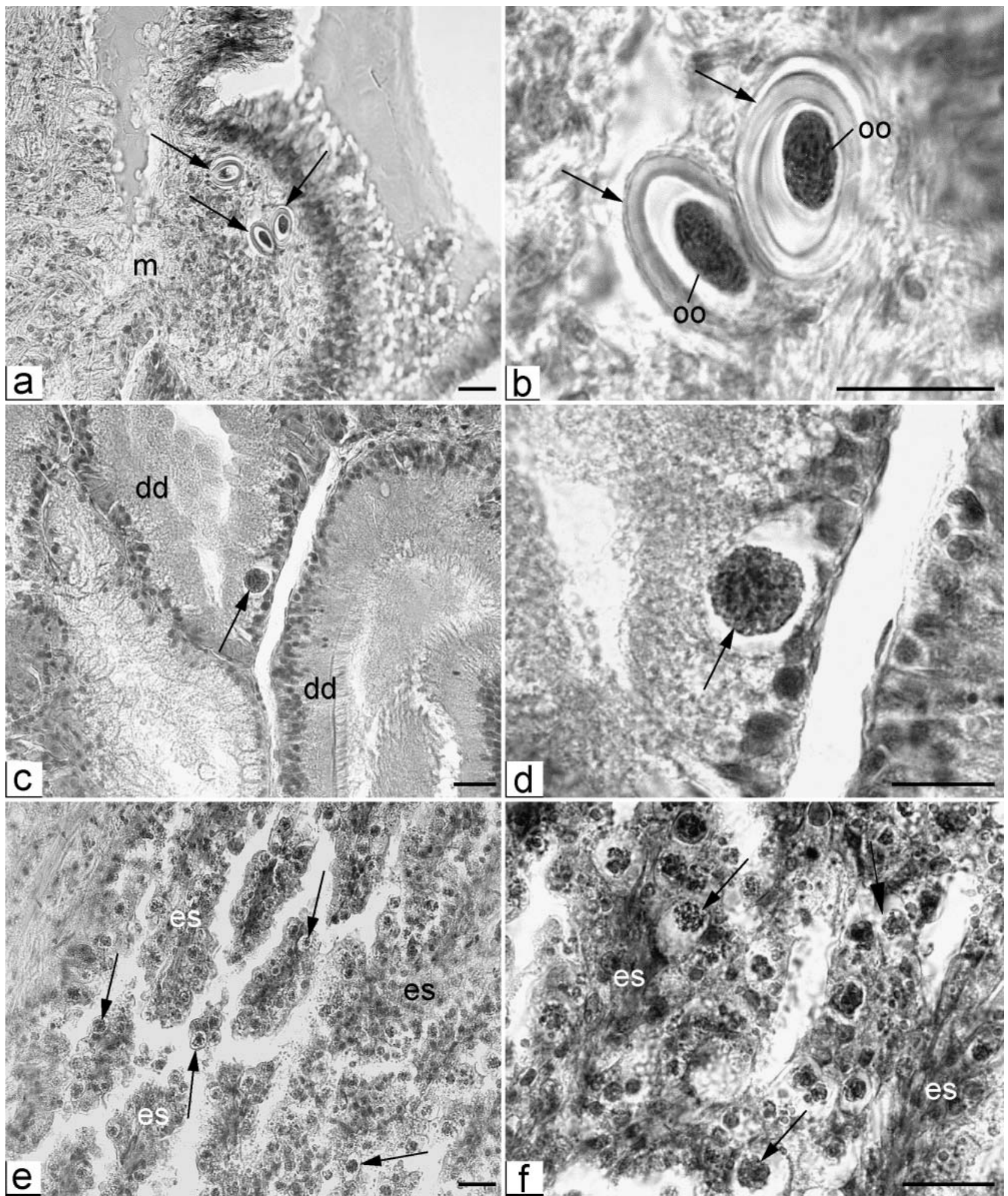

Fig. 3. Types of parasites in Lepetodrilus elevatus and L. fucensis. (a) Unidentified gregarine protozoan (arrows) parasitizing mantle tissue (m) of L. elevatus; (b) gregarine oocyst (oo) within sporocysts (arrows); (c) Bacterial Inclusion I (arrow) in the digestive diverticula (dd) of L. elevatus; d) Bacterial Inclusion I (arrow) in L. elevatus (note individual bacteria in spherical clusters); (e) Bacterial Inclusion II (arrows) in esophageal tissue (es) of L. fucensis; (f) same as (e), but higher magnification of Bacterial Inclusion II (arrows) in esophageal tissue (es). Scale bars $=20 \mu \mathrm{m}$ 
Of 2 bacterial gut inclusions, 1 (Bacterial Inclusion I) was found in epithelial cells of the digestive diverticula of Lepetodrilus elevatus from both East Pacific Rise vent sites (Fig. 3c). Bacterial Inclusion I was a basophilic, irregularly shaped bacterial colony, averaging $15 \mu \mathrm{m}(\mathrm{n}=10)$ in diameter and made up of rodshaped bacteria $\sim 1 \mu \mathrm{m}$ in length. Unlike the rickettsialike inclusions, Bacterial Inclusion I lacked an outer membrane (Fig. 3d).

A second bacterial parasite, Bacterial Inclusion II, was observed in the esophageal tissue of Lepetodrilus elevatus from the Oasis vent and $L$. fucensis from the Endeavour vent (Fig 3e). Individual, spherical aggregates were observed under high power and ranged in diameter from 5 to $10 \mu \mathrm{m}$ ( $\mathrm{n}=10$; Fig. 3f). Inclusions were basophilic with $\mathrm{H} \& \mathrm{E}$ stain.

We observed 2 types of parasites in Paralepetopsis floridensis from the Florida Escarpment seep site. Of these, 1 parasite type matched the Bacterial Inclusion I (described above) found in Lepetodrilus elevatus from the East Pacific Rise. The second parasite type was a rickettsia-like gut inclusion, Digestive Rickettsia III, found only in P. floridensis. Digestive Rickettsia III ranged in diameter from 25 to $30 \mu \mathrm{m}(\mathrm{n}=3)$ and was thus larger than the previous 2 rickettsia-like gut inclusions described. Digestive Rickettsia III infected the epithelial cells of the digestive tract (Fig. 4a). These inclusions were diffuse, with a filamentous internal

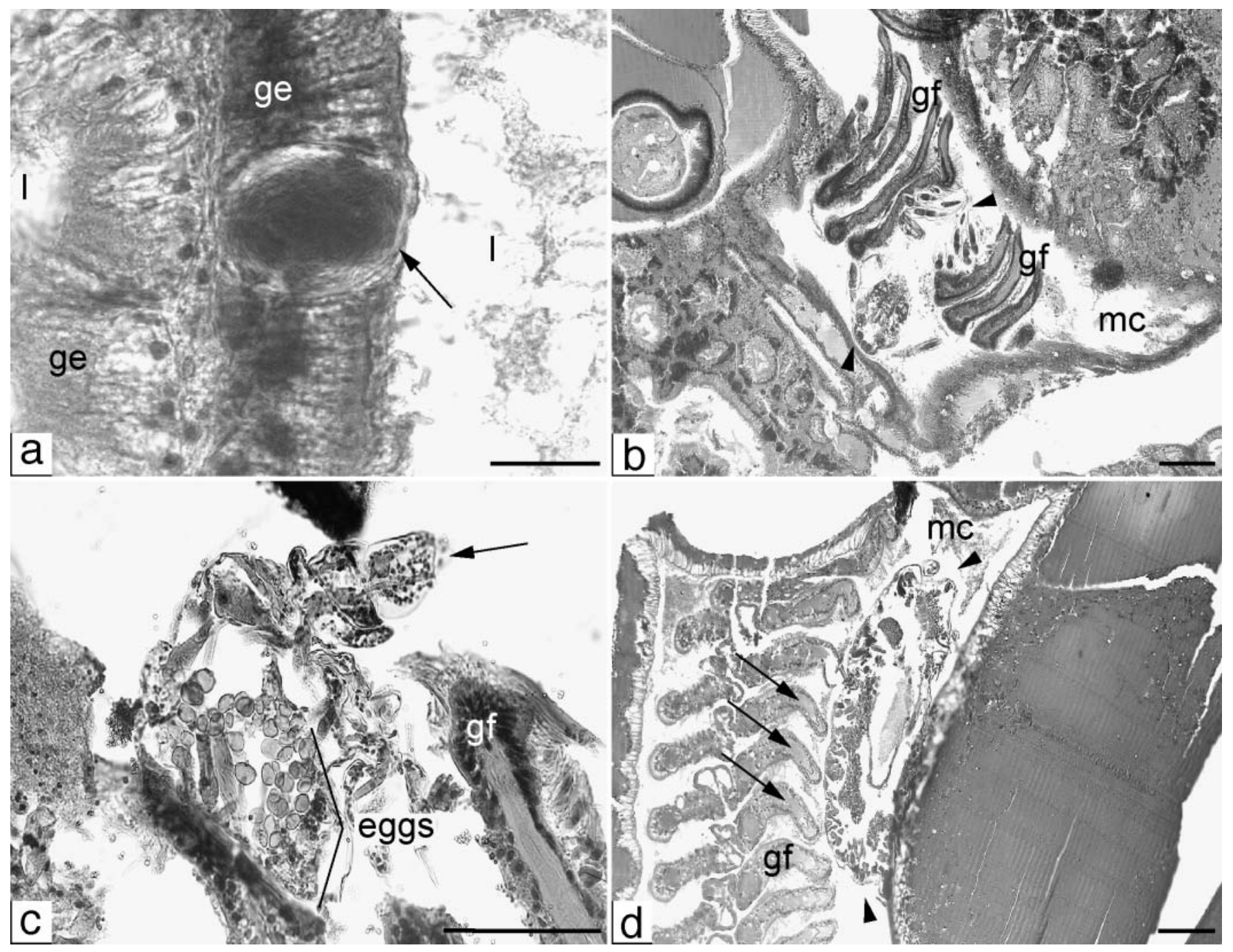

Fig. 4. Types of parasites in Paralepetopsis floridensis, and copepods in Lepetodrilus elevatus, Pseudorimula midatlantica, and L. fucensis. (a) Digestive Rickettsia III (arrow) in gut epithelium (ge) of P. floridensis (l= lumen); (b) copepod in longitudinal section (between arrowheads), displacing gill filaments (gf) in mantle cavity (mc) of L. elevatus; (c) gravid copepod (arrow) between gill filaments (gf) in P. midatlantica; (d) copepod (between arrowheads) in mantle cavity (mc) of L. fucensis, with gill filament (gf) displacement evident (arrows). Scale bar for (a) $=20 \mu \mathrm{m}$, for (b), (c), (d) = $100 \mu \mathrm{m}$ 
structure and with edges lacking a clear definition (Fig. 4a). Inclusions were basophilic with H\&E stain. The inclusions appeared to be breaking through the host cell membrane.

\section{Copepods}

Unidentified copepods were observed in histological sections of 6 limpets (Table 1). Copepods were found between gill filaments in the mantle cavities of limpets (Fig. 4b), and ranged in size from 165 to $471 \mu \mathrm{m}$ in length. Female copepods were recognized by the presence of eggs (Fig. 4c). Little tissue damage was observed that could be attributed to the presence of the copepods. Gill filaments were usually pushed aside or apart to make room for the copepod (Fig. 4a,d) and a weak hemocytic response (i.e. increased number of hemocytes) was sometimes observed in the area surrounding the copepod.

\section{Parasite distribution, prevalence and infection intensity in limpets}

The highest diversity of parasites was found in Lepetodrilus elevatus from vents on the East Pacific Rise. We found 6 types of parasites in L. elevatus from Oasis; 3 of these were found in L. elevatus from East Wall (Fig. 5). L. fucensis limpets from the Endeavour vent site had 2 types of parasites; these were also a subset of the 6 types found in L. elevatus from Oasis (Table 1, Fig. 5). No parasite type was common to all vent limpet species; 1 parasite, the gregarine protozoan, was only found in 2 female L. elevatus from Oasis (Table 1). No parasites were found in Pseudorimula midatlantica from the Snake Pit vent site.

Nearly $50 \%$ of limpets sampled from vents had 1 or more parasites $(60 \%$ if Snake Pit limpets are excluded). Mean infection intensity was variable (16 \pm 28 SD parasites per infected limpet). Lepetodrilus elevatus from Oasis and East Wall vents each had total parasite prevalences (no. of individuals infected with any parasite) of $>60 \%$, but mean infection intensity was nearly 5 times higher at Oasis than at East Wall (Fig. 5), due primarily to the occurrences of Bacterial Inclusion II (Table 1). L. fucensis from the Juan de Fuca vent site had a total prevalence of $52 \%$, and a mean infection intensity of about 16 parasite occurrences per limpet (Fig. 5). As in L. elevatus, Bacterial Inclusion II contributed most to the mean infection intensity in $L$. fucensis (Table 1)

There was a significant separation in parasite composition and abundance in infected individuals of Lepetodrilus elevatus from East Wall and L. fucensis from the Endeavour vent ( $\mathrm{R}=0.662$; ANOSIM; Fig. 6), consistent with the observation that these 2 sites do not share any types of parasites. Parasite burdens in L. elevatus from Oasis vents could not be distinguished from parasite burdens in $L$. elevatus from East Wall or from parasite burdens in $L$. fucensis from Endeavour vents ( $\mathrm{R}<0.294$; ANOSIM; Fig. 6).

Of the 8 Paralepetopsis floridensis limpets sampled from the Florida Escarpment seep, 4 were infected with a parasite, but mean infection intensities were low (1 to 2 parasites individual ${ }^{-1}$; Table 1 ).

\section{DISCUSSION}

The most dramatic difference in parasite burdens among the 4 species of limpets examined was the apparent absence of any parasite type in Pseudorimula
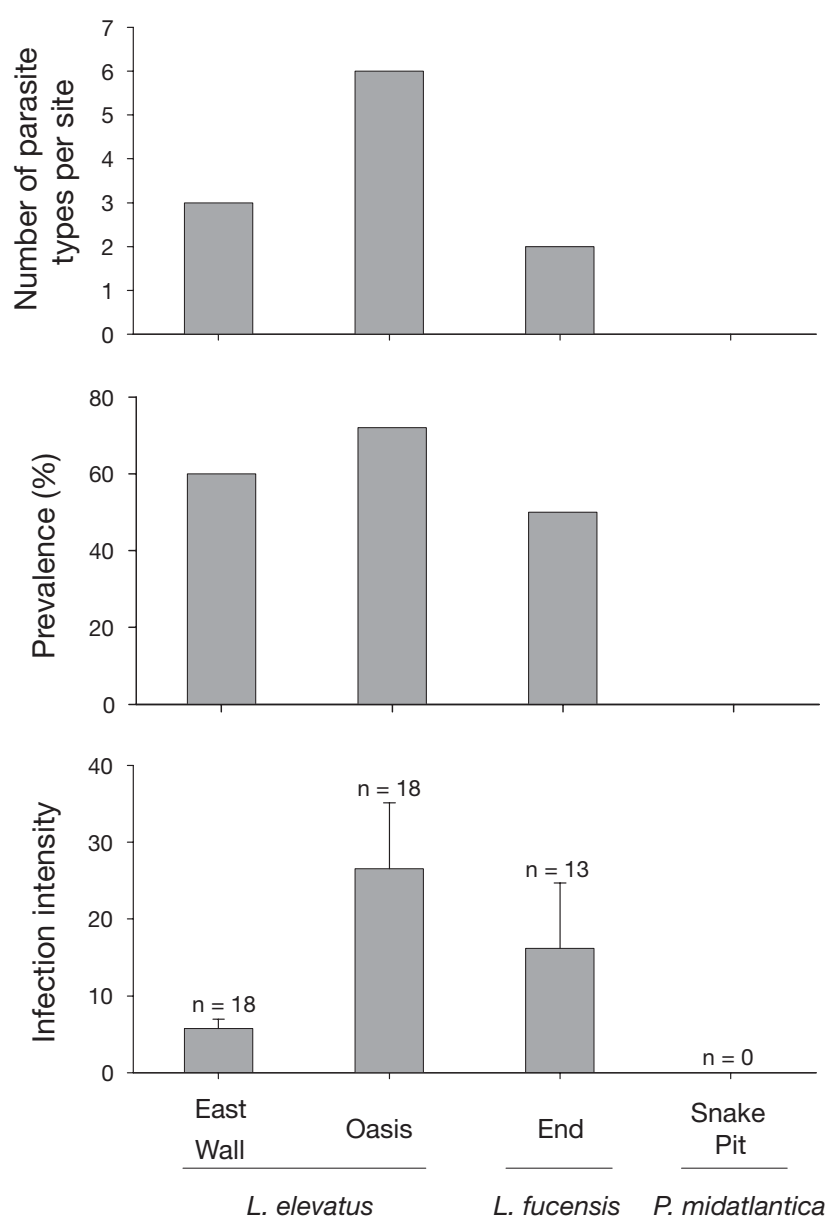

Fig. 5. Lepetodrilus elevatus, L. fucensis, and Paralepetopsis floridensis. Number of parasite types per site, parasite prevalence (percentage of host individuals infected with any parasite), and mean infection intensity (mean number of all parasites per infected individual). $\mathrm{n}$ : number of infected individuals; End: Endeavour 


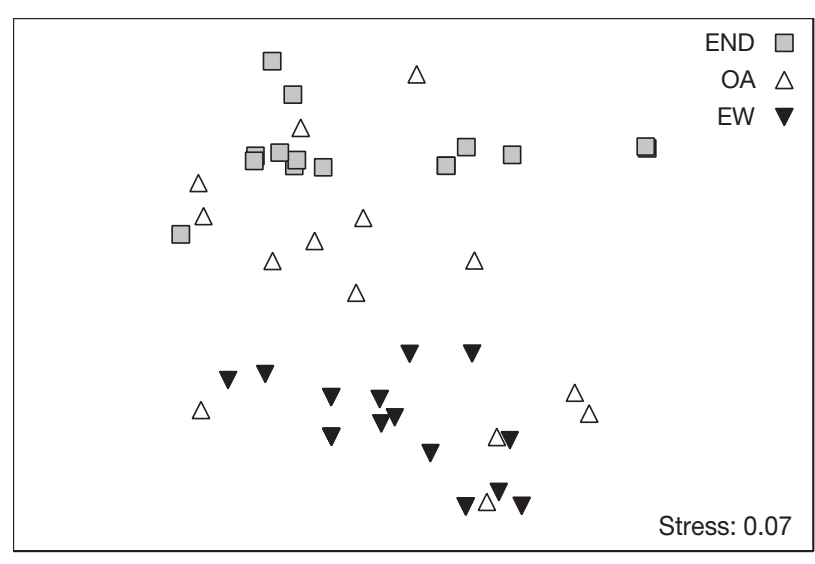

Fig. 6. Unitless MDS plot derived from parasite type-infection intensity matrix. END: Endeavour limpets (Lepetodrilus elevatus); OA: Oasis limpets (L. elevatus); EW: East Wall limpets (L. elevatus). Distances between samples represent dissimilarity in parasite types (and their abundance) infecting individual hosts

midatlantica of the Mid-Atlantic Ridge vent. In contrast, vent limpets from the East Pacific Rise vents and the Juan de Fuca Ridge vent were infected by 3 to 6 types of parasites, with prevalences as high as $72 \%$. Our study was clearly not comprehensive, and a more ambitious survey of parasite burdens is needed to determine if low parasite diversity is typical of MidAtlantic Ridge vent invertebrates. Lower invertebrate diversity on the MAR compared to the EPR is known for mussel-bed communities (Van Dover \& Trask 2000, Turnipseed et al. 2003, M. Doerries \& C. L. Van Dover pers. comm.) and has been attributed to the greater spacing between vents on the MAR (Baker et al. 1995) that in turn may result in a greater probability of extinction due to dispersal limitation (Van Dover 1995). Other non-exclusive explanations for lower diversity at MAR vents, including greater habitat area on the EPR, are possible (Juniper \& Tunnicliffe 1997).

The 2 populations of Lepetodrilus elevatus that we sampled (East Wall and Oasis populations) were separated by $27^{\circ}$ of latitude and shared 3 types of parasites (Bacterial Inclusion I, Digestive Rickettsia I, and Digestive Rickettsia II). The Oasis population had higher parasite intensities and overall greater parasite diversity than the East Wall population. Higher parasite intensities are often correlated with greater host population densities (Price 1990), but in this case, limpet densities at Oasis were 1 order of magnitude lower than limpet densities at East Wall (Van Dover 2003). L. elevatus and its congener, L. fucensis from the Juan de Fuca Ridge vent site, shared 2 types of parasites (Bacterial Inclusion II and Gill Rickettsia). More definitive, molecular characterization of the parasites is required before we can be sure that these are shared species. To our knowledge, L. fucensis is the only vent limpet species known to be colonized by endosymbiotic bacteria (de Burgh \& Singla 1984), yet it had the lower parasite prevalence of the 2 congeners. In bathymodiolin mussels from deep-sea seeps and vents, parasitic infection was correlated with endosymbiont density (Ward et al. 2004).

We found 2 types of parasites specific to a single species and/or site: the gregarine protozoan was only found in Lepetodrilus elevatus from the Oasis vent on the East Pacific Rise; Digestive Rickettsia III was only found in Paralepetopsis floridensis from the Florida Escarpment seep. In general, gregarines and rickettsia-like parasites are not host-specific in shallowwater molluscs (Lauckner 1983); we anticipate that further sampling effort will reveal these types of parasites to be present elsewhere.

All types of parasites found in vent and seep limpets are known to occur in shallow-water molluscs. Gregarines are a common, benign parasite of shallowwater marine molluscs (Lauckner 1983), with prevalences of up to $100 \%$ in some cockle populations (Carballal et al. 2001). In vent and seep limpets, however, gregarines have low prevalences, and no gregarines have been identified in mussels from seeps or vents (Powell et al. 1999, Ward et al. 2004).

Rickettsia-like infections represent another parasite type commonly found in shallow-water marine molluscs. Prevalence of rickettsia-like parasites was higher in EPR (East Wall and Oasis) limpets and Juan de Fuca (Endeavour) limpets (up to $52 \%$ of the individuals sampled) than commonly found in intertidal mussels and cockles (Kim et al. 1998, Carballal et al. 2001). Rickettsia-like parasites were also identified in Bathymodiolus spp. mussels from seeps (Powell et al. 1999, Ward et al. 2004) and vents (Ward et al. 2004). Prevalences of rickettsia-like parasites were lower in EPR and Juan de Fuca Ridge vent limpets than observed in shallow-water hydrocarbon seep mussels by Powell et al. (1999) or in some deep-sea seep and vent mussels by Ward et al. (in press). Rickettsia-like infections have been occasionally linked to fatal diseases in shallowwater molluscs (Lauckner 1983). For example, rickettsia-like infections are implicated in the withering syndrome in Haliotis cracherodii (Gardner et al. 1995) and in mortalities of Placopecten magellanicus (Gulka et al. 1983). In most cases, high intensities of a rickettsia-like infection are required before the infection becomes fatal (Lauckner 1983). Low intensities of rickettsia-like infections in vent limpets suggest that it is unlikely that these infections were detrimental to their hosts. No evidence for rickettsia-related mortality was found in Bathymodiolus spp. mussels from seeps Powell et al. 1999, Ward et al. 2004) or vents (Ward et al. 2004). 
We did not find 2 common molluscan parasites, trematodes and viral inclusions, in vent limpets. Trematodes are harmful parasites that occur in molluscs in both coastal environments and shallow-water seeps (Kim et al. 1998, Powell et al. 1999, Montaudouin et al. 2000), but trematode infections have yet to be observed in deep-sea hydrothermal-vent or seep molluscs (Ward et al. 2004, and present study). The absence of trematodes from vents and seeps could be due to environmental factors and the lack of a suitable intermediate host (Ward et al. 2004). Although relatively common in intertidal molluscs, viral infection has not been observed in shallow-water seep mussels or deep-sea limpets (Lauckner 1983, Powell et al. 1999, this study), but a virus has been inferred to have a negative influence on the population structure of a seep mussel (Ward et al. 2004).

Copepods were found between gill filaments and in the mantle cavities of limpets from EPR, MAR and Juan de Fuca Ridge vent fields, but they did not appear to have a detrimental effect on their hosts. Copepod infestation of vent limpets was not correlated with parasite infection of the limpets. The appearance of copepods in marine molluscs, especially in mussels, is not uncommon (Lauckner 1983). Copepods are most frequently associated with the gills and the mantle cavity, where they are rarely observed to cause damage to the organism, and in the digestive tract, where infestation can cause tissue destruction (Lauckner 1983, CáceresMartínez \& Vásquez-Yeomans 1997, Boxshall 1998). Copepods found near gills and in the mantle cavity are typically thought to have a commensal relationship with their host, and may be adapted to acquire food with the assistance of their host's feeding mechanism (Lauckner 1983). Examination of additional copepodinfested individuals is needed to clarify the relationship between limpets and copepods.

Although we detected no evidence for a strong influence of parasites on host limpet population dynamics in the material we examined from deep-sea chemosynthetic environments, we did discover parasites that have the potential to be ecologically important. It would be useful to track parasite burdens in populations exposed to different environmental conditions within a vent field over the duration of active venting. This kind of time-series and habitat-quality approach to parasitological ecology would complement more traditional ecological approaches that consider population dynamics of invertebrates in relation to habitat quality or biological interactions involving competition, predation, and facilitation.

Acknowledgements. This study was the undergraduate research thesis of C.M.T. Field sampling was supported by the National Science Foundation (OCE-988550, OCE9982999) and by the NOAA National Undersea Research Pro- gram at the University of North Carolina, Wilmington. J. Shields and S. Ford assisted with parasite type characterization. The College of William \& Mary provided funds for laboratory aspects of this research.

\section{LITERATURE CITED}

Anderson RM (1978) The regulation of host population growth by parasite species. Parasitology 76:119-157

Anderson RM, May RM (1978) Regulation and stability of host-parasite population interactions. I. Regulatory processes. J Anim Ecol 47:219-247

Baker ET, German CR, Elderfield H (1995) Hydrothermal plumes over spreading-center axes: global distributions and geological inferences. In: Humphris SE, Zierenberg RA, Mullineaux LS, Thomsen RE (eds) Seafloor hydrothermal systems: physical, chemical, and geochemical interactions. Geophys Monogr 91. American Geophysical Union, Washington, DC, p 47-71

Boxshall GA (1998) Host specificity in copepod parasites of deep-sea fishes. J Mar Syst 15:215-223

Cáceres-Martínez J, Vásquez-Yeomans R (1997) Presence and histopathological effects of the copepod Pseudomyicola spinosus in Mytilus galloprovincialis and Mytilus californianus. J Invertebr Pathol 70:150-155

Calvo-Ugarteburu G, McQuaid CD (1998) Parasitism and invasive species: effects of digenetic trematodes on mussels. Mar Ecol Prog Ser 169:149-163

Carballal MJ, Iglesias D, Santamarina J, Ferro-Soto B, Villalba A (2001) Parasites and pathologic condition of the cockle Cerastoderma edule populations of the coast of Galicia (NW Spain). J Invertebr Pathol 78:87-97

Clarke KR, Gorley RN (2001) PRIMER v5: user manual/ tutorial. PRIMER-E, Plymouth

Cosson RP, Vivier JP (1997) Interactions of metallic elements and organisms within hydrothermal vents. Cah Biol Mar 38:43-50

de Burgh ME, Singla CL (1984) Bacterial colonization and endocytosis on the gill of a new limpet species from a hydrothermal vent. Mar Biol 84:1-6

Gardner GR, Harshbarger JC, Lake JL, Sawyer TK, Price KL, Stephenson MD, Haaker PL, Togstad HA (1995) Association of prokaryotes with symptomatic appearance of withering syndrome in black abalone Haliotis cracherodii. J Invertebr Pathol 66:111-120

Gulka G, Chang PW, Marti KA (1983) Rickettsiales-like infection in the gills of Placopecten magellanicus. J Fish Dis 6 : 355-364

Juniper SK, Tunnicliffe V (1997) Crustal accretion and the hot vent ecosystem. Phil Trans R Soc Lond A 335:459-474

Kim Y, Powell EN, Wade TL, Presley BJ, Sericano J (1998) Parasites of sentinel bivalves in the NOAA status and trends program: distribution and relationship to contaminant body burden. Mar Pollut Bull 37:45-55

Lauckner G (1983) Chapter 14: Disease of mollusca: Bivalvia. In: Kinne $\mathrm{O}$ (ed) Disease of marine animals, Vol. II: Bivalvia to Scaphopoda. Biologische Anstalt Helgoland, Hamburg, p 477-879

MacDonald IR, Guinasso ML Jr, Reilly JF, Brooks JM, Callender WR, Gabrielle SG (1990) Gulf of Mexico hydrocarbon seep communities. VI. Patterns in community structure and habitat. Geo-Mar Lett 10:244-252

Margolis L, Esch GW, Holmes JC, Kuris AM, Schad GA (1982) The use of ecological terms in parasitology (report of an ad hoc committee of the American Society of Parasitologists). J Parasitol 68:131-133 
Montaudouin X, Kisieleeshki I, Bachelet G, Desclaux C (2000) A census of macroparasites in an intertidal bivalve community, Arcachon Bay, France. Oceanol Acta 23:453-468

Paull CK, Hecker B, Commeau R, Freeman-Lynde RP and 6 others (1984) Biological communities at the Florida Escarpment resemble hydrothermal vent taxa. Science 226:965-967

Poulin R (2002) Parasites in marine systems. Parasitology 124: S1

Powell EN, Barber RD, Kennicutt II MC, Ford SE (1999) Influence of parasitism in controlling the health, reproduction, and PAH body burden of petroleum seep mussels. DeepSea Res I 46:2053-2078

Price PW (1990) Host populations as resources defining parasite community organization. In: Esch GW, Bush A, Aho J (eds) Parasite communities: patterns and processes. Chapman \& Hall, New York, p 21-40

Sibuet M, Olu K (1998) Biogeography, biodiversity, and fluid dependence of deep-sea cold-seep communities at active and passive margins. Deep-Sea Res II 45:517-567

Stevens A (1990) The haematoxylins. In: Bancroft JD, Stevens A (eds) Theory and practice of histological techniques.

Editorial responsibility: Albert Sparks,

Seattle, Washington, USA
Churchill Livingstone, New York, p 107-118

Turnipseed M, Knick KE, Lipcius RN, Dreyer J, Van Dover CL (2003) Biodiversity hotspots at cold seeps? Ecol Lett 6: 518-523

Van Dover CL (1995) Ecology of Mid-Atlantic Ridge hydrothermal vents. Spec Publ Geol Soc Lond 87:257-294

Van Dover CL (2000) The ecology of deep-sea hydrothermal vents. Princeton University Press, Princeton, NJ

Van Dover CL (2003) Variation in community structure within hydrothermal vent mussel beds of the East Pacific Rise. Mar Ecol Prog Ser 253:255-266

Van Dover CL, Trask JL (2000) Diversity at deep-sea hydrothermal vent and intertidal mussel beds. Mar Ecol Prog Ser 195:169-178

Van Dover CL, Aharon P, Bernhard JM, Caylor E and 15 others (2003) Blake Ridge methane seeps: characterization of a soft-sediment, chemosynthetically based ecosystem. Deep-Sea Res I 50:281-300

Ward ME, Shields JD, Van Dover CL (2004) Parasitism in species of Bathymodiolus (Bivalvia: Mytilidae) mussels from deep-sea seep and hydrothermal vents. Dis Aquat Org 62:1-16

Submitted: July 30, 2003; Accepted: March 18, 2004 Proofs received from author(s): November 1, 2004 